\title{
VDAC1 wt Allele
}

National Cancer Institute

\section{Source}

National Cancer Institute. VDAC1 wt Allele. NCI Thesaurus. Code C51093.

Human VDAC1 wild-type allele is located within $5 q 31$ and is approximately $33 \mathrm{~kb}$ in length.

This allele, which encodes voltage-dependent anion-selective channel protein 1 , is involved in the regulation of diffusion and apoptosis. 